\title{
Comparison of del Nido cardioplegia and St. Thomas Hospital solution - two types of cardioplegia in adult cardiac surgery
}

\author{
Prashant Mishra, Ranjit B. Jadhav, Chandan Kumar Ray Mohapatra, Jayant Khandekar, Chaitanya Raut, \\ Ganesh Kumar Ammannaya, Harsh S. Seth, Jaskaran Singh, Vaibhav Shah
}

Department of Cardiovascular Thoracic Surgery, Lokmanya Tilak Municipal Medical College and General Hospital, Mumbai, India

Kardiochirurgia i Torakochirurgia Polska 2016; 13 (4): 295-299

\begin{abstract}
Introduction: St. Thomas' cardioplegic solution No. 2 (ST), although most widely used in adult cardiac surgery, needs to be given at short intervals, causing additional myocardial injury. Aim: To determine whether del Nido (DN) cardioplegia, with longer periods of arrest, provides equivalent myocardial protection as compared to ST.

Material and methods: The study population comprised 100 patients who underwent elective coronary artery bypass grafting (CABG) or double valve replacement (DVR) surgery between January 2015 and January 2016. The patients were divided into two groups based on the type of cardioplegia administered during surgery: 1$)$ intermittent ST (ST, $n=50)$ and 2) DN cardioplegia (DN, $n=50$ ). We compared the aortic cross clamp (CC) and cardiopulmonary bypass (CPB) times, number of intra-operative DC shocks required, and postoperative changes in left ventricular ejection fraction (LVEF) in the two groups. Results: The aortic cross clamp and bypass times were shorter with DN (110.15 \pm 36.84 vs. $133.56 \pm 35.66$ and $158.60 \pm 39.92$ vs. $179.81 \pm 42.36$ min respectively, $p<0.05)$. Fewer cardioplegia doses were required in the DN group vs. the ST group (1.38 \pm 0.59 vs. $4.15 \pm 1.26 ; p=0.001$ ), while a single cardioplegia dose was given to $35 \mathrm{DN}$ patients $(70 \%)$ vs. 0 ST patients $(p<0.001)$. Postoperative LVEF was better preserved in the DN group. Conclusions: The use of DN leads to shorter cross clamp and CPB times, reduces cardioplegia dosage, and provides potentially better myocardial protection in terms of LVEF preservation, with a safety profile comparable to ST cardioplegia. Key words: del Nido cardioplegia, St. Thomas' solution.
\end{abstract}

\section{Introduction}

Myocardial protection during open heart surgery has been the focus of clinical research for many decades, but the debate regarding the ultimate cardioprotective strategy

\section{Streszczenie}

Wstęp: Roztwór kardioplegiczny St. Thomas II (ST), choć szeroko stosowany w zabiegach chirurgicznych u dorosłych pacjentów, musi być podawany w krótkich odstępach czasu, co powoduje dodatkowe uszkodzenie mięśnia sercowego.

Cel: Ustalenie, czy kardioplegia del Nido (DN) charakteryzująca się dłuższym okresem zatrzymania pracy serca oferuje równorzędną ochronę mięśnia sercowego w porównaniu z ST.

Materiat i metody: Badaniem objęto 100 pacjentów, których poddano planowym zabiegom pomostowania aortalno-wieńcowego (CABG) lub wymiany zastawki mitralnej i aortalnej (DVR) pomiędzy styczniem 2015 a styczniem 2016 roku. Badana populacja została podzielona na dwie grupy w zależności od kardioplegii podawanej w czasie zabiegu: 1) przerywanej kardioplegii ST (ST, $n=50$ ) lub 2) kardioplegii DN (DN, $n=50)$. Porównano czas zaklemowania aorty i czas krążenia pozaustrojowego, liczbę defibrylacji i pooperacyjną zmianę frakcji wyrzutowej lewej komory (LVEF) w obu grupach.

Wyniki: Czasy zaklemowania aorty i krążenia pozaustrojowego były krótsze przy stosowaniu kardioplegii DN (odpowiednio $110,15 \pm 36,84$ vs $133,56 \pm 35,66$ oraz $158,60 \pm 39,92$ vs 179,81 $\pm 42,36 \mathrm{~min}, p<0,05)$. W grupie DN liczba wymaganych dawek kardioplegii była mniejsza $(1,38 \pm 0,59$ vs $4,15 \pm 1,26$; $p=0,001)$, a pojedynczą dawkę kardioplegii podano 35 (70\%) pacjentom z grupy DN i żadnemu pacjentowi z grupy ST $(p<0,001)$. Również wyniki LVEF były lepsze w grupie DN.

Wnioski: Stosowanie kardioplegii DN wiąże się z krótszym czasem zaklemowania aorty i krążenia pozaustrojowego, mniejszymi dawkami kardioplegii oraz oferuje potencjalnie lepszą ochronę mięśnia sercowego w zakresie utrzymania LVEF przy profilu bezpieczeństwa porównywalnym z kardioplegią ST. Słowa kluczowe: kardioplegia del Nido, roztwór St. Thomas.

and the search for the ideal cardioplegic solution are still ongoing. In the early 1990s, Dr. Pedro del Nido and his team at the University of Pittsburgh developed a cardioplegic solution to address the specific needs of immature myocardi-

Address for correspondence: Chandan Kumar Ray Mohapatra MBBS, MS in General Surgery, Department of Cardiovascular Thoracic Surgery, Lokmanya Tilak Municipal Medical College and General Hospital, CVTS RR, $2^{\text {nd }}$ Floor, EMS Building, Sion Hospital, Lokmanya Tilak Municipal Government Hospital, 400022 Mumbai, India, phone: +91 9820050634, e-mail: bapun39@gmail.com

Received: 23.07.2016, accepted: 10.10.2016. 
Tab. I. Composition of St Thomas (ST) and del Nido (DN) cardioplegia solutions

\begin{tabular}{ll} 
ST cardioplegia & \\
$\mathrm{Na}^{+}$ & $110 \mathrm{mmol} / \mathrm{l}$ \\
\hline $\mathrm{K}^{+}$ & $16 \mathrm{mmol} / \mathrm{l}$ \\
\hline $\mathrm{Mg}^{2+}$ & $16 \mathrm{mmol} / \mathrm{l}$ \\
\hline $\mathrm{Ca}^{2+}$ & $1.2 \mathrm{mmol} / \mathrm{l}$ \\
\hline $\mathrm{NaHCO}_{3}{ }^{-}$ & $10 \mathrm{mmol} / \mathrm{l}$ \\
\hline DN cardioplegia & \\
\hline Mannitol & $20 \%, 16.3 \mathrm{ml}, 3.26 \mathrm{~g}$ \\
\hline Magnesium sulfate & $50 \%, 4 \mathrm{ml}, 2 \mathrm{~g}$ \\
\hline Sodium bicarbonate & $8.4 \%, 13 \mathrm{ml}, 13 \mathrm{mEq}$ \\
\hline Lidocaine & $1 \%, 13 \mathrm{ml}, 130 \mathrm{mg}$ \\
\hline Potassium chloride $(2 \mathrm{mEq} / \mathrm{ml})$ & $13 \mathrm{ml}, 26 \mathrm{mEq}$ \\
\hline
\end{tabular}

um encountered in neonatal and pediatric cardiac surgery. The solution, now commonly referred to as del Nido (DN) cardioplegia, induces a depolarizing arrest during cardiac surgery. It is more dilute $(1: 4$, blood : crystalloid) as compared to the traditional $4: 1$ blood cardioplegia; it has less $\mathrm{Ca}^{2+}$ and contains lidocaine [1] (Tab. I).

St. Thomas' cardioplegic solution No. 2 (ST) has been a popular crystalloid cardioplegia among cardiac surgeons; however, it must be administered repeatedly at short intervals during the surgery. Increases in myocardial acidosis between the doses have been noted, affecting the postoperative outcome adversely [2, 3]. Thus, it would be beneficial if the interval between the cardioplegic doses could be increased, thereby reducing the number of doses required during surgery. The DN's potential practical advantage is the fact that it provides a long period of arrest before a subsequent dose is needed [4]. Investigators have begun reporting their clinical experiences with DN in adult hearts and have achieved good outcomes with a single dose or longer intervals between doses, leading to shorter crossclamp times [5-8].

\begin{abstract}
Aim
The aim of this study is to evaluate the efficacy and safety of DN as compared to ST in adults undergoing elective coronary artery bypass grafting (CABG) and double valve replacement (DVR) surgery. We decided to include the longer DVR procedure as few cases requiring prolonged cardiac arrest using the DN solution have been included in previous studies.
\end{abstract}

\section{Material and methods \\ Patient population}

This retrospective study was conducted at the Department of Cardiovascular and Thoracic Surgery of Lokmanya Tilak Municipal Medical College \& Sion Hospital. Consecutive patients undergoing elective CABG or DVR surgery were retrospectively studied from January 2015 to January 2016; they were divided into two cohorts based on the type of cardioplegia administered during surgery: 1) intermittent St. Thomas' No. 2 cardioplegia (ST, $n=50)$ used in patients from January 2015 until June 2015, and 2) del Nido cardioplegia (DN, $n=50$ ) used from June 2015 to January 2016. Demographic details and clinical outcome data were retrospectively collected from patient files and our department's computerized patient records; they included patient age, sex, comorbid medical conditions such as diabetes, hypertension, etc., as well as preoperative left ventricular ejection fraction (LVEF). The intra- and postoperative details collected for the two cohorts included cardiopulmonary bypass (CPB) time, aortic cross clamp (CC) time, the number of cardioplegia doses, intraoperative DC shocks required, postoperative LVEF, and in-hospital mortality.

\section{Cardioplegia administration}

All procedures were performed using a standard general anesthesia protocol, median sternotomy approach, and cardiopulmonary bypass with mild systemic hypothermia (30 to $34^{\circ} \mathrm{C}$ ). Myocardial protection was achieved with either ST or DN cardioplegia as follows. In both groups, the heart was arrested with an induction dose (1 l) of cold $\left(4^{\circ} \mathrm{C}\right)$ cardioplegia using antegrade and/or retrograde delivery (Tab. I). In addition, repeated doses of ST cardioplegia were given to ST patients only. A second dose $(500 \mathrm{ml})$ of DN was provided only when the cross clamp time exceeded $90 \mathrm{~min}$.

\section{Statistical analysis}

The data were analyzed using SPSS version 10. Continuous variables were reported as mean \pm standard deviation and compared using the independent samples $t$-test. Categorical variables were reported as frequency and percentage of the total group and compared using Pearson's $\chi^{2}$ test or Fisher's exact test where applicable. All $p$-values $\leq 0.05$ were considered significant.

\section{Results}

\section{Baseline demographics}

A total of 100 patients were studied: 50 in the St. Thomas' No. 2 group (ST group) and 50 in the del Nido group (DN group). Thirty-four (68\%) patients underwent CABG in the ST group as compared to $36(72 \%)$ patients in the DN group, while DVR was performed in 16 (32\%) and 14 (28\%) patients in the ST and DN groups, respectively. The overall mean age of the patients was $51.86 \pm 13.4$ years (range: 16-74 years). All other demographic characteristics of the patients in the two study groups were similar, as shown in Table II.

\section{Intra- and postoperative variables and outcomes}

The intra- and postoperative outcome details are presented in Table III. The aortic cross clamp and cardiopulmonary bypass times during both CABG and DVR surgery using del Nido cardioplegia were significantly reduced as compared to the ST group. Additionally, the administration 
Tab. II. Baseline demographics

\begin{tabular}{lccc} 
Variable & ST & DN & P-value \\
Total $n$ & 50 & 30 & $36(72)$ \\
\hline CABG, $n(\%)$ & $34(68)$ & $14(28)$ & 0.657 \\
\hline DVR, $n(\%)$ & $16(32)$ & $52.48 \pm 13.05$ & 0.639 \\
\hline Age [years] & $50.96 \pm 14.13$ & $37(74)$ & 0.798 \\
\hline Gender (male), $n(\%)$ & $39(78)$ & $40(80)$ & 0.585 \\
\hline Diabetes, $n(\%)$ & $41(82)$ & $41(82)$ & 0.195 \\
\hline Hypertension, $n(\%)$ & $43(86)$ & $50.00 \pm 12.86$ & 0.308 \\
\hline LVEF $(\%$, mean \pm SD): & & $47.22 \pm 13.03$ & 0.305 \\
Total & $53.80 \pm 09.60$ & $57.77 \pm 10.77$ & \\
CABG & $50.31 \pm 10.56$ & & \\
DVR & $60.00 \pm 0.00$ & & \\
\hline
\end{tabular}

Tab. III. Intra- and postoperative profile

\begin{tabular}{lcccc} 
Variable & Procedure & ST & DN & P-value \\
Number of grafts & CABG & $3.8 \pm 0.67$ & $4 \pm 0.62$ & 0.310 \\
\hline \multirow{3}{*}{ Aortic cross clamp time, mean \pm SD [min] } & Total & $133.56 \pm 35.66$ & $110.15 \pm 36.84$ & 0.012 \\
& DVR & $152.11 \pm 24.99$ & $128.77 \pm 22.74$ & 0.034 \\
& CABG & $128.28 \pm 37.11$ & $104.22 \pm 38.50$ & 0.043 \\
\hline \multirow{2}{*}{ Cardiopulmonary bypass time, mean \pm SD [min] } & Total & $179.81 \pm 42.36$ & $158.60 \pm 39.92$ & 0.041 \\
& DVR & $198.78 \pm 27.87$ & $177.69 \pm 17.30$ & 0.040 \\
& CABG & $172.83 \pm 46.07$ & $143.85 \pm 45.39$ & 0.043 \\
\hline \multirow{3}{*}{ Number of doses of cardioplegia, mean \pm SD (range) } & Total & $4.15 \pm 1.26(2-7)$ & $1.38 \pm 0.59(1-3)$ & 0.001 \\
& DVR & $4.78 \pm 1.39(2-7)$ & $1.46 \pm 0.66(1-3)$ & 0.001 \\
& CABG & $3.83 \pm 1.10(2-6)$ & $1.33 \pm 0.55(1-3)$ & 0.001 \\
\hline \multirow{3}{*}{ Intraoperative DC shocks required, $n$ (\%) } & Total & $2(4)$ & $2(4)$ & 1.000 \\
& DVR & $1(6.2)$ & $1(7.1)$ & 0.922 \\
Inotropic usage, $n$ (\%) & CABG & $1(2.9)$ & $1(2.7)$ & 0.967 \\
\hline \multirow{2}{*}{ ABP usage, $n$ (\%) } & Total & $26(52)$ & $23(46)$ & 0.548 \\
& DVR & $14(87.5)$ & $12(85.7)$ & 0.885 \\
& CABG & $12(35.2)$ & $11(30.5)$ & 0.817 \\
\hline \multirow{2}{*}{ In-hospital mortality, $n$ (\%) } & Total & $1(2)$ & 0 & 0.314 \\
& DVR & 0 & 0 & 1.000 \\
& CABG & $1(2.9)$ & 0 & 0.300 \\
\hline
\end{tabular}

of DN cardioplegia resulted in a significantly lower number of required doses as compared to the ST group (1.38 \pm 0.59 vs. $4.15 \pm 1.26$; $p=0.001$ ). A single cardioplegia dose was given to 35 (70\%) DN patients, while ST patients required at least 2 (and up to a maximum of 7) doses of cardioplegia. There was no significant difference between the two groups in the percentage of cases in which intraoperative DC shocks were required.

Twenty-six (52\%) patients in the ST group and 23 (46\%) patients in the DN group needed inotropic drug support during the time between aortic declamping and being transported to the intensive care unit. The difference between the two groups was not statistically significant $(p=0.72)$. In the ST group, one CABG patient required intraoperative intra-aortic balloon counterpulsation (IABP).

Postoperatively, the overall mean LVEF showed a significant fall of 3.3\% among the ST group and an insignificant rise of $2.5 \%$ among the DN group in comparison with the pretreatment values. When compared, the change was significantly more pronounced in the ST group than in the DN group. This change in LVEF was mainly observed in the CABG group, as presented in Table IV. Although this information was not routinely recorded, we did not observe any noticeable intergroup differences in the time to restoration of cardiac rhythm or time to weaning from bypass.

In-hospital mortality was higher in the ST group, but the difference was not statistically significant $(p=0.314)$. One (2\%) patient in the ST group died during CABG due to profound cardiogenic shock; there was no hospital mortality in the DN group.

\section{Discussion}

Cardioplegic solutions have a key role in protecting the heart from myocardial injury during open heart surgery. The DN solution has been used successfully in pediatric cardiac surgery $[1,4,9]$; however, its use in adult cardiac surgery 
Tab. IV. Comparison of changes in mean LVEF between the groups by procedure

\begin{tabular}{|c|c|c|c|c|c|c|c|}
\hline \multirow[t]{3}{*}{ Procedure } & \multicolumn{6}{|c|}{ Mean LVEF } & \multirow[t]{3}{*}{$P$-value } \\
\hline & \multicolumn{3}{|c|}{ ST $(N=50)$} & \multicolumn{3}{|c|}{ DN $(N=50)$} & \\
\hline & Pre & Post & Change & Pre & Post & Change & \\
\hline Total & $53.80 \pm 9.60$ & $52.00 \pm 10.41$ & $-1.80 \pm 4.05^{*}$ & $50.00 \pm 12.86$ & $51.25 \pm 11.02$ & $1.25 \pm 7.99$ & $0.046^{*}$ \\
\hline DVR & $60.00 \pm 0.00$ & $58.89 \pm 2.20$ & $-1.11 \pm 2.20^{*}$ & $57.77 \pm 10.77$ & $54.69 \pm 12.18$ & $-3.08 \pm 10.32$ & $\begin{array}{c}0.248 \\
\text { NS }\end{array}$ \\
\hline CABG & $50.31 \pm 10.56$ & $48.13 \pm 11.24$ & $-2.18 \pm 4.82^{*}$ & $47.22 \pm 13.03$ & $50.56 \pm 10.59$ & $3.34 \pm 5.72^{\star}$ & $0.001^{*}$ \\
\hline
\end{tabular}

NS - not significant, ${ }^{*}$ significant.

has only recently been described [5-8]. The proposed benefit of this solution is the avoidance of the need for repetitive interruption of the procedure to administer multiple doses of standard cardioplegia, which leads to shorter cross clamp times. In this study, we present our experience with DN cardioplegia in patients undergoing elective CABG or DVR and compare it with our cohort of patients who received ST cardioplegia.

Shorter CC and CPB times in the operations utilizing DN were the primary findings apparent from our study, which is consistent with earlier studies using DN in adult patients $[5,7,8]$. This can be attributed to the reduced requirement to administer repeated doses of cardioplegia. The CC and CPB times in the present study were, however, longer than those reported in previously published studies in adult patients. This was expected due to the inclusion of longer procedures (DVR and CABG with multiple grafting) in our study. A single dose of cardioplegia was administered to $70 \%$ of our patients in the DN group, with the rates reported in adult studies from different centers ranging from $40 \%$ to $84 \%[5,7]$. The lower rate of $40 \%$ reported by Smigla et al. can be attributed to their re-dosing policy of $45 \mathrm{~min}$ as compared with 90 min in our study. Less frequent dosing allows the surgeon to operate uninterrupted and decreases the risk of contamination. These advantages of DN may facilitate myocardial protection during adult cardiac surgery.

Lower rates of immediate postoperative complications and mortality with the use of DN were observed in our data, but the differences did not reach statistical significance. Nonetheless, superior protection of DN over ST and a comparable safety profile can be predicted from the improved postoperative LVEF in the DN group noted in our study. Accelerated accumulation of intracellular $\mathrm{Ca}^{2+}$ during myocardial ischemia mediates the early reperfusion injury that occurs during cardiac surgery [10-12]. The myocardial cell counteracts this high intracellular $\mathrm{Ca}^{2+}$ through energy requiring active transport mechanisms and ultimately manifesting as myocardial dysfunction upon reperfusion. The DN contains lidocaine, a membrane-stabilizing agent which increases $\mathrm{Na}^{+}$channel blockade and minimizes the potential for a $\mathrm{Na}^{+}$window current. Together with its $\mathrm{Mg}^{2+}$ content acting as a $\mathrm{Ca}^{2+}$ antagonist, these are the suggested mechanisms by which DN cardioplegia protects the myocardium from high intracellular $\mathrm{Ca}^{2+}[9]$.

O'Blenes et al. previously reported that, in isolated aged rat cardiomyocytes, cardiac arrest with DN cardioplegia re- sulted in lower spontaneous activity during ischemia, lower diastolic $\mathrm{Ca}^{2+}$ during ischemia and reperfusion, and avoidance of $\mathrm{Ca}^{2+}$-induced hypercontraction during early reperfusion in comparison with standard cardioplegia [12]. Later, they also showed that, in a similar setting of aged hearts, single-dose DN cardioplegia was also associated with superior calcium handling of cardiomyocytes, reduced myocardial injury, and improved functional recovery [13]. However, these findings need to be confirmed using more clinically relevant methodology, and their effect on long-term postoperative ventricular function should be examined.

\section{Limitations of the study}

The limitations of our study include its retrospective, descriptive nature and small cohort size. Moreover, only postoperative hemodynamic parameters were used to assess myocardial protection, while biochemical parameters such as postoperative cardiac enzymes could have enabled better analysis of direct cardiac injury. Finally, no long-term follow-up of myocardial protection (e.g., changes in regional wall motion or ejection fraction) was performed. More prospective longterm studies must be designed to explore the applications of DN cardioplegia and to validate our current findings.

\section{Conclusions}

Our study showed that the use of DN cardioplegia reduced the time of CC and CPB as well as the need for repeated doses of cardioplegia. Additionally, it provided potentially better myocardial protection in view of the preserved LVEF values, with a safety profile and mortality comparable to ST cardioplegia. To our knowledge, our data are the first to show that DN cardioplegia is a beneficial alternative to ST cardioplegia even in longer procedures such as DVR.

\section{Disclosure}

Authors report no conflict of interest.

The study was approved by the ethics committee of our institution; because of its retrospective nature, patient consent was waived. The cardiac procedures performed using different cardioplegic solutions were in accordance with the routine standard of care being followed at the institution during that period. Consent for surgery was obtained routinely from all individual participants included in the study. This research received no specific grant from any funding agency in the public, commercial, or non-profit sectors. 


\section{References}

1. Matte GS, del Nido PJ. History and use of del Nido cardioplegia solution at Boston Children's Hospital. JECT 2012; 44: 98-103.

2. Graffigna AC, Nollo G, Pederzolli C, Ferrari P, Widesott L, Antolini R. Continuous monitoring of myocardial acid-base status during intermittent warm blood cardioplegia. Eur J Cardiothorac Surg 2002; 21: 995-1001.

3. Khuri SF, Healey NA, Hossain M, Birjiniuk V, Crittenden MD, Josa M, Treanor PR, Najjar SF, Kumbhani DJ, Henderson WG. Intraoperative regional myocardial acidosis and reduction in long-term survival after cardiac surgery. J Thorac Cardiovasc Surg 2005; 129: 372-381.

4. Charette K, Gerrah R, Quaegebeur J, Chen J, Riley D, Mongero L, Corda R, Bacha $E$. Single dose myocardial protection technique utilizing del Nido cardioplegia solution during congenital heart surgery procedures. Perfusion 2012; 27: 98-103.

5. Smigla G, Jaquiss R, Walczak R, Bonadonna D, Kaemmer D, Schwimer C, Lodge A. Assessing the safety of del Nido cardioplegia solution in adult congenital cases. Perfusion 2014; 29: 554-558.

6. Sorabella RA, Akashi H, Yerebakan H, Najjar M, Mannan A, Williams MR, Smith CR, George I. Myocardial protection using del Nido cardioplegia solution in adult reoperative aortic valve surgery. J Card Surg 2014; 29: 445-449.

7. Yerebakan H, Sorabella RA, Najjar M, Castillero E, Mongero L, Beck J, Hossain M, Takayama H, Williams MR, Naka Y, Argenziano M, Bacha E, Smith CR, George I. Del Nido cardioplegia can be safely administered in high-risk coro- nary artery bypass grafting surgery after acute myocardial infarction: a propensity matched comparison. J Cardiothorac Surg 2014; 9: 141.

8. Mick SL, Robich MP, Houghtaling PL, Gillinov AM, Soltesz EG, Johnston DR, Blackstone EH, Sabik JF 3rd. Del Nido versus Buckberg cardioplegia in adult isolated valve surgery. J Thorac Cardiovasc Surg 2015; 149: 626-634.

9. O'Brien JD, Howlett SE, Burton HJ, O'Blenes SB, Litz DS, Friesen CL. Pediatric cardioplegia strategy results in enhanced calcium metabolism and lower serum troponin T. Ann Thorac Surg 2009; 87: 1517-1523.

10. Bolling K, Kronon M, Allen BS, Ramon S, Wang T, Hartz RS, Feinberg H. Myocardial protection in normal and hypoxically stressed neonatal hearts: the superiority of hypocalcemic versus normocalcemic blood cardioplegia. J Thorac Cardiovasc Surg 1996; 112: 1193-1200.

11. Tsukube T, McCully JD, Federman M, Krukenkamp IB, Levitsky S. Develop mental differences in cytosolic calcium accumulation associated with surgically induced global ischemia: optimization of cardioplegic protection and mechanism of action. J Thorac Cardiovasc Surg 1996; 112: 175-184.

12. O'Blenes SB, Friesen CH, Ali A, Howlett S. Protecting the aged heart during cardiac surgery: the potential benefits of del Nido cardioplegia. J Thorac Cardiovasc Surg 2011; 141: 762-770.

13. Govindapillai A, Hua R, Rose R, Friesen CH, O'Blenes SB. Protecting the aged heart during cardiac surgery: use of del Nido cardioplegia provides superior functional recovery in isolated hearts. J Thorac Cardiovasc Surg 2013; 146: 940-948. 